\title{
Wine growers face new complexities
}

$\mathrm{W}$ hat a difference a decade makes. The growth of California's wine industry is remarkable, particularly since 1991 — not coincidentally, the year "60 Minutes" popularized results of a study that found moderate wine consumption can reduce the risk of heart disease. Thanks to a robust U.S. economy and ever-growing demand for premium wines (a specialty of California's North Coast and Central Coast regions), grape production and related industries now infuse $\$ 33$ billion into the state's economy, and California now produces well over $90 \%$ of the nation's wine grapes, according to the Wine Institute.

The most obvious sign of all this activity is the skyrocketing level of vineyard plantings. Recent reports from the Allied Grape Growers and California Agricultural Statistics Service indicate the state hâs increased its vineyard acreage by $53 \%$ since 1990 and now has an estimated 554,000 acres planted in grapes, with 40,000 acres coming into production as new vineyards this year alone. In Santa Barbara County, home to some of the largest new vineyards, acreage has jumped from 9,000 to 20,000 acres in the past 4 years. In Sonoma County, more than 50,000 acres are now planted in grapes, and projects involving 9,000 more acres were submitted to the agricultural commissioner at the end of 1999 (see pp. 7-20).

Can the runaway growth continue? At a Vineyard Economics Seminar in Napa this May, analysts predicted a bumper crop will hit the market in the fall that will cause a sharp drop in grape prices from areas that produce lower-cost wines, such as the Central Valley. But while many expressed confidence that the demand for premium wines will continue to rise, Peter Opatz, president of the Sonoma County Grape Growers Association, (SCGGA) sees change on the horizon in the North Coast. "I do think the 2000 vintage could be the one that stops the boom," he says, "because of the unprecedented number of planted acres, coupled with the best technology going into the newer vineyards. Not only are we seeing more acres in production, we're seeing higher production per acre."
Perhaps more threatening to the industry than economic downturns are plant pathogens. Today, the most serious threat is Pierce's disease (see p. 4), caused by Xyllela bacteria and transmitted by sharpshooters. "The state of California has a long and costly history with Pierce's disease, in which entire grape-growing areas have been devastated," Opatz says. "North Coast growers already have experienced an estimated $\$ 10$ million in crop loss annually due to the disease." The disease has reached epidemic proportions in Temecula, Riverside County, and glassy-winged sharpshooters - the insect vector - are moving ever closer to the North Coast. "I'm very concerned about the current epidemic in Temecula," Opatz says, "because I believe our [Xylella] bacterial load in the natural landscape is far greater than it is in Temecula. The glassy-winged sharpshooter and the North Coast's bacterial load have potentially far-reaching ramifications for growers in our area."

When not contending with market fluctuations and plant diseases, growers are facing heightened public scrutiny and attempts to regulate their activities. In Sonoma County, an ordinance enacted this past fall prohibits vineyard planting on slopes of more than $50 \%$, requires erosion control plans for slopes over $10 \%$ and prohibits planting of vines on hillsides within 50 feet of streams. The result of 2 years of negotiations among growers, land-use planners and environmental groups, the ordinance has been mired in controversy since it took effect. Environmental advocates want protection of redwoods and oaks, particularly in west country, and some decry the "industrial model" of vineyard operations they believe are destroying their rural landscapes and way of life.

"Growers have not been especially receptive to being regulated for the very first time in their history," Opatz admits. "But the vast majority understand the need to protect our waterways for listed species like the coho salmon and steelhead trout. We see this as an absolutely necessary process for our own sustainability."

"I do think that $95 \%$ of vineyardists are taking responsible steps," says Bill Kortum, a 


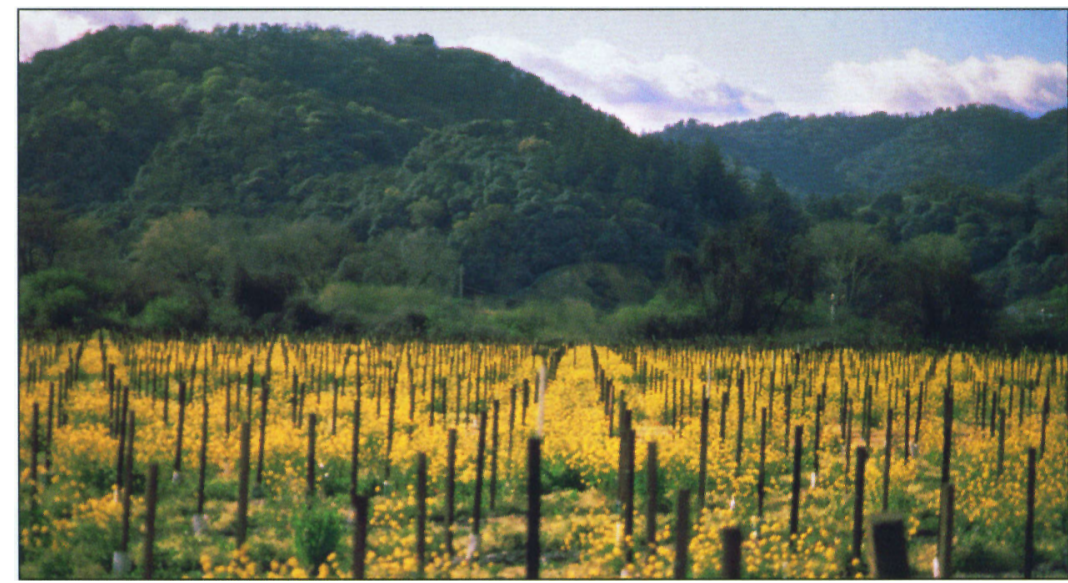

The state has increased its vineyard acreage $53 \%$ since 1990.

hobby grape grower and cofounder of Sonoma County Conservation Action. "It's that $5 \%$ that disregards the natural landscape that is creating the need for these ordinances. They spell out the rules we all must play by; I believe they're a step in the right direction."

Napa County is trying to update its own erosion-control ordinance, originally enacted in 1991. Last year the Sierra Club filed a lawsuit against the county for its discretionary review process for hillside planting; since the suit was settled in the fall, the county has provided heightened environmental review for all agricultural projects on slopes between $5 \%$ and $30 \%$.

"Environmental review with regard to agriculture is not a precise science," says Napa County planner Jeffrey Redding, "Neither growers nor planners are sure what the effects of the Sierra Club lawsuit will be."

Santa Barbara County has enacted a grading ordinance requiring growers to obtain a county permit when there is potential for significant impact from planting on slopes or deep cutting of earth. And county supervisors recently drafted an ordinance requiring growers to submit plans to the county before removing oak trees.

But area growers' biggest challenge comes from a federal, rather than local, regulation. In January the U.S. Fish and Wildlife Service gave endangered species emergency listing status to the California tiger salamander, which lives in vernal pools frequently located on land slated for vineyard development in Santa Barbara County. Farmers face up to a year in jail and a $\$ 50,000$ fine for harming the salamander. "The salamander is a huge story down here, bigger even than the oak trees," says county planner Abe Leider. For now, adds Peggy Burbank, a fellow county planner and tiger salamander project manager, the Fish and Wildlife Service has told property owners they can work their existing vineyards without risk of regulatory action, as long as they incorporate prescribed practices a reprieve for this growing season.

Federal actions to slow development of wetlands and vernal pools are occurring elsewhere. In November, a federal judge imposed a $\$ 1.5$ million fine - the largest wetlands civil penalty ever imposed after trial by a U.S. court against a Sacramento Valley developer who, in the process of converting nearly a thousand acres of wetlands into vineyards, destroyed two acres harboring threatened fairy shrimp. And in May the U.S. Environmental Protection Agency announced a $\$ 100,000$ grant to protect Central Valley vernal pools from development.

Amid the burgeoning government regulations and oversight, UC researchers are beginning to provide the scientific data that can elucidate the scope and impact of vineyard expansion in the state, including new applications of geographic information systems by UC Berkeley Cooperative Extension specialist Adina Merenlender and others (pp. 7-20). UC Berkeley Professor Peter Berck, a resource economist working with Merenlender, says "An important part of predicting future production and prices [of grapes] is a solid knowledge of current bearing and nonbearing acreage. With more accurate price and acreage predictions, producers will be less likely to overplant. Accurately measuring this acreage by remote-sensing techniques and then finding the relation between the acreage and future prices is the subject of our ongoing research."

"Merenlender's team did ground-breaking work; it's the first one out of the chute," says Sonoma County's Opatz, whose group (SCGGA) provided data to the research team. While questions remain about the study's findings, he says, "We definitely support getting good planting data, and I think growers appreciate long-term planning for resource use and the scientific work to back that up, because we cannot do our job without it."

Planners say their biggest challenge will be to strike a balance between agriculture and the environment. "Our responsibility is to propose regulations that do not put undue burden on our agricultural industry and yet allow for some protection of our most important natural resources," says Santa Barbara County's Leider. "Agriculture is our No. 1 industry. As land-use planners, we love to see agriculture thrive, because it's a land use that is generally beneficial-and an integral part of the heritage of California." - Jill Goetz 